\title{
Spectral Reflectance in the Spatial-temporal Dynamic of Turbidity, Itaipu Reservoir, Brazil
}

\author{
Reflectância Espectral na Dinâmica Espaço-temporal da Turbidez, Reservatório de Itaipu, Brasil
}

\section{Douglas Stefanello Facco ${ }^{1}$ (i), Laurindo Antonio Guasselli' (i), Luis Fernando Chimelo Ruiz ${ }^{2}$ (1), João Paulo Delapasse Simioni ${ }^{1}$ (1) \& Daiane Gerhardt Dick ${ }^{3}$}

\author{
'Universidade Federal do Rio Grande do Sul, Centro Estadual de Pesquisas em Sensoriamento Remoto e Meteorologia, \\ Porto Alegre, RS, Brasil \\ 2Universidade de São Paulo, Escola Superior de Agricultura Luiz de Queiroz, São Paulo, SP, Brasil \\ ${ }^{3}$ Universidade Federal do Rio Grande do Sul, Instituto de Pesquisas Hidráulicas (IPH), Porto Alegre, RS, Brasil \\ E-mail: douglas.s.facco@gmail.com; laurindo.guasselli@ufrgs.br; ruiz.ch@gmail.com; geojoaopaulo@gmail.com; \\ daiidick@hotmail.com
}

\begin{abstract}
Water quality and the useful life of reservoirs and dams are influenced by the entry of suspended solids, in addition to reducing their transparency and storage capacity. It is primary to monitor and analyses its space-time dynamics. Thus, the objective of this work is to characterize the dynamics of the Itaipu Reservoir waters from turbidity, rainfall and spectral reflectance data. To characterize the dynamics, the reservoir was divided into 18 aquatic compartments between upstream and downstream, using precipitation data from the TRMM sensor and Landsat 8 images in different precipitation situations. NDWI, MNDWI and NDTI water spectral indexes were calculated from Landsat 8 images. The results showed high correlation between the NDTI index and the turbidity $\left(\mathrm{R}^{2}=0.91\right)$. Then the NDTI images were reclassified into low, medium and high turbidity. A strong correlation between turbidity and 4 Band corresponding to the spectral range of red $\left(\mathrm{R}^{2}=0.94\right)$ was also obtained. The precipitation has a determinant influence, being the Paraná River, in the periods of greater precipitation, the main agent in sediment transport. The space-time dynamics showed that the lateral compartments of the reservoir have less influence on sediment transport. In this sense, our analysis brought new elements to understand the turbidity variation in these Itaipu Reservoir compartments, as well as the spectral reflectance dynamics in the space-time characterization related to turbidity.
\end{abstract}

Keywords: Suspended solids; NDTI; Landsat-8/OLI

\section{Resumo}

A qualidade das águas e a vida útil de reservatórios e barragens são influenciados pela entrada de sólidos suspensos, além de diminuir a sua transparência e capacidade de armazenamento. O monitoramento e análise de sua dinâmica espaço-temporal é primordial. Assim, o objetivo desse trabalho é caracterizar a dinâmica a partir de dados de turbidez, da precipitação pluviométrica e da reflectância espectral das águas do reservatório Itaipu. Para caracterizar a dinâmica, o reservatório foi dividido em 18 compartimentos aquáticos entre a montante e jusante, e utilizou-se dados de precipitação do sensor TRMM e imagens Landsat 8 em diferentes situações de precipitação. A partir das imagens Landsat 8 foram calculados índices espectrais de água NDWI, MNDWI e NDTI. Os resultados mostraram alta correlação entre o índice NDTI e a turbidez $\left(\mathrm{R}^{2}=0,91\right)$. Então as imagens de NDTI foram reclassificadas em baixa, média e alta turbidez. Também foi obtido forte correlação entre a turbidez e a Banda 4, correspondente à faixa espectral do vermelho $\left(\mathrm{R}^{2}=0,94\right)$. A precipitação possui influência determinante, sendo o rio Paraná, nos períodos de maior precipitação, o principal agente no transporte de sedimentos. A dinâmica espaço-temporal mostrou que os compartimentos laterais do reservatório possuem menor influência no transporte de sedimento. Nesse sentido, nossa análise trouxe novos elementos para entender a variação da turbidez nesses compartimentos do reservatório de Itaipu, e entender a dinâmica da reflectância espectral na caracterização espaço-temporal relacionada a turbidez.

Palavras-chave: Sólidos suspensos; NDTI; OLI/ Landsat-8 


\section{Introduction}

Large reservoirs and dams are influenced by leaching, silting, surface runoff, soil erosion, waste discharge and runoff phenomena, which lead to the entry of suspended solids. These optically active components affect the quality of reservoir water and its useful life, since they decrease both transparency and storage capacity of water bodies (Chalov et al. 2015; Davranche, Lefebvre \& Poulin 2010; Ma et al. 2007; Somvanshi et al. 2011; Trinh et al. 2018). Reservoirs play an important role in the control and management of water resources, hydropower generation, water supply, agricultural irrigation and recreation (Haibo et al. 2011; Lu et al. 2011; Wang et al. 2018).

Turbidity is an important limnological variable that makes it possible to quantify both the reduction of water transparency and the interference in the passage of light in reservoirs. In summary, the higher the total amount of suspended solids, the higher the turbidity, as cited by Somvanshi et al. (2011), for example. In many cases, the continuous monitoring of reservoirs is not feasible, given their location in remote or inaccessible regions (Alsdorf, Rodríguez \& Lettenmaier 2007; Barbosa, Novo \& Martins 2019; Wang et al. 2004; Zhang \& Liu 2014).

Given the difficulties of monitoring large reservoirs and the limitations of conventional methods, remote sensing technology is an alternative with the potential to provide crucial information in space-time monitoring on water bodies in which in-situ networks are not available (Alsdorf, Rodríguez \& Lettenmaier 2007; Barbosa, Novo \& Martins 2019; Haibo et al. 2011; Zhang \& Liu 2014).

The analysis of turbidity in reservoir monitoring from remote sensing tools is very promising. The relationships between turbidity and semianalytical models are highlighted (Abe et al. 2019; Potes, Costa \& Salgado 2012; Zhang et al. 2016). By using turbidity estimation models, Garg, Aggarwal \& Chauhan (2020) report the sensitivity of both red and near infrared (NIR) bands of the Sentinel-2. Chelotti et al. (2019), by generating an estimation model of suspended solids for a low concentration reservoir, and studying its relations with the rainfall regime, from images Landsat 8, highlighted that the spectral range of red allowed the analysis of the spatial behavior of the water body. Allam, Khan \& Meng (2020) developed a regional algorithm to recover surface turbidity with Landsat 8 surface reflectance (L8SR) images, reporting the importance of applying this model in environments of comparable morphological characteristics.

Studies with a space-time approach, such as Pinto et al. (2014), which analyzed 12 years of (Earth and Aqua) MODIS images, pointed out a strong relationship between solids and spectral reflectance, by using turbidity attribute and MODIS NIR/Red sensor bands data, Robert et al. (2016), considering the spectral range of red (Lobo, Costa \& Novo 2015; Martins et al. 2019; Quang et al. 2017; Yanti, Susilo \& Wicaksono 2016).

Important results have also been obtained with Normalized Difference Turbidity Index (NDTI) (Baughman et al. 2015; Bid \& Siddique 2019), Normalized Difference Water Index (NDWI) (Ouni et al. 2019; Saberioon et al. 2020; Wang, Gong \& Pu 2018) and Modified Normalized Difference Water Index (MNDWI) (Faye et al. 2020; Maliki et al. 2020; Mi et al. 2019) spectral reflectance indices.

Brazil is the country with the highest availability of fresh water in the world. Most of this water is stored in approximately 19,000 artificial reservoirs whose volume varies in time and space due to both climatic and economic factors, such as energy production and irrigation demands (Barbosa, Novo \& Martins 2019). The large extension of Itaipu reservoir, with a flooded area of $1,350 \mathrm{~km}^{2}$ Itaipu (2020), deserves attention regarding its monitoring, allowing to explore methodologies with remote sensing techniques. The dynamics of the Itaipu Reservoir have a strong seasonal influence of rainfall (Grimm 1988), which constitutes a significant factor in the fluctuations of the limnological variables of transparency (Toniolo et al. 2019), suspended solids (Silva et al. 2019) and turbidity (Ribeiro Filho 2006; Ribeiro Filho 2008; Ribeiro Filho et al. 2011).

In this context, our goal is to characterize the spatialtemporal dynamic from the relationship between turbidity, rainfall and spectral reflectance data for the Itaipu Reservoir waters.

Our work brings new elements to understand the variation of turbidity in the Itaipu Reservoir and to understand the dynamics of spectral reflectance in spatialtemporal characterization. The products generated are an alternative for monitoring other reservoirs.

\section{Area of Study and Methodology}

\subsection{Area of Study}

Itaipu Hydroelectric Power Plant reservoir is located on the Paraná River, on the border between Brazil and Paraguay, and it extends itself from Foz do Iguaçu/ Ciudad del Este cities to the city of Guaíra, in the north (Agostinho et al. 1999) (Figure 1). The reservoir is part of the Paraná basin 3. The main tributaries of the Paraná River in Brazilian territory are the São Francisco River, with source in Cascavel, the Guaçu River, which rises in the Toledo city, the São Francisco Falso River, in Céu Azul city, and the Ocoí River, in Matelândia city (Secretaria de Estado do Meio Ambiente e Recursos Hídricos do Paraná 2013). 


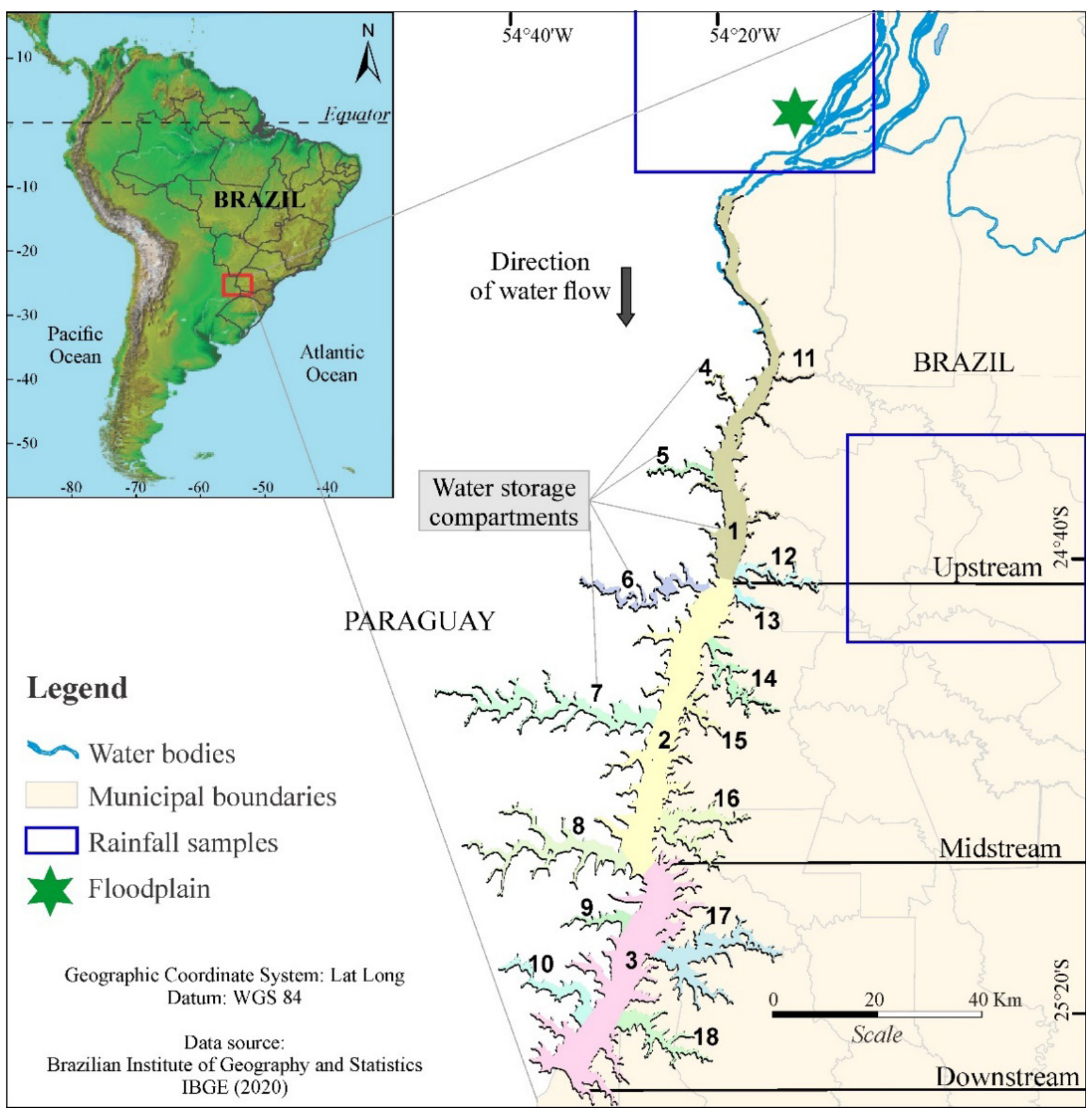

Figure 1 Location map of Itaipu Reservoir Power Plant Reservoir study area: precipitation sampling areas, aquatic compartments and flood plain.

In 2016 Itaipu Binacional was the first hydroelectric plant in the world to exceed the annual generation of 100 million megawatt-hours (MWh), the plant surpassed the 2014 record of 98.8 million MWh set by the Chinese company Três Gargantas and recovered the world's first place in annual production of clean and renewable energy. Itaipu is also the largest hydroelectric plant in the world in accumulated production. Since it started operating in May
1984, more than 2.4 billion MWh have been generated (Itaipu 2020).

In Itaipu Reservoir upstream area there is an extensive flood plain of the Upper Paraná River (Galvão, Stevaux \& Saad 2014; Stevaux, Martins \& Meurer 2009), with around $230 \mathrm{~km}$ long and variable width between 3 $\mathrm{km}$ and $8 \mathrm{~km}$. This area is limited between the Engenheiro Sérgio Mota Hydroelectric Power Plant downstream and 
the beginning of the backwater of Itaipu Hydroelectric Power Plant reservoir. The flood plain has hygrophilous vegetation with high humidity characteristics as its main modelling agent (Couto, Hayakawa \& Souza-Filho 2010).

The predominant climate in the region is classified as Cfa, subtropical humid, which is mesothermal, with annual precipitation average between 1,600 $\mathrm{mm}$ and 1,700 $\mathrm{mm}$. There is a higher concentration of rainfall during the summer months, without a defined dry season. The average temperatures of the hottest months are above $22^{\circ} \mathrm{C}$ and the coldest months are below $18^{\circ} \mathrm{C}$ (Instituto Agronômico do Paraná 2020; Souza Filho \& Fragal 2013).

The main use of the land is agriculture in the basin area. The predominant type of soil is the Latosol that corresponds to soils in advanced stages of weathering, typical of both equatorial and tropical regions, also occurring in subtropical zones. The latosols are mainly distributed by large and old erosion surfaces or river terraces, usually in flat and smooth wavy relief (Rocha \& Bade 2018).

\subsection{Methodological Flowchart}

The methodology used to understand the spatialtemporal variation of turbidity is presented in the methodological flowchart (Figure 2).

\subsection{Reservoir Compartmentalization}

Due to its large extension, the Itaipu Reservoir presents different dynamics from downstream to upstream, as well as in the compartments of its horizontal arms. Thus, the compartmentation of the reservoir is fundamental to establish areas with similar environmental conditions. A reservoir may have several aquatic compartments with one or more common characteristics, but they communicate with each other in the transportation of energy and matter, directing changes in time and space (Wachholz 2011).

The criteria for the reservoir compartmentalization followed Wachholz, Pereira Filho \& Sartor (2011)

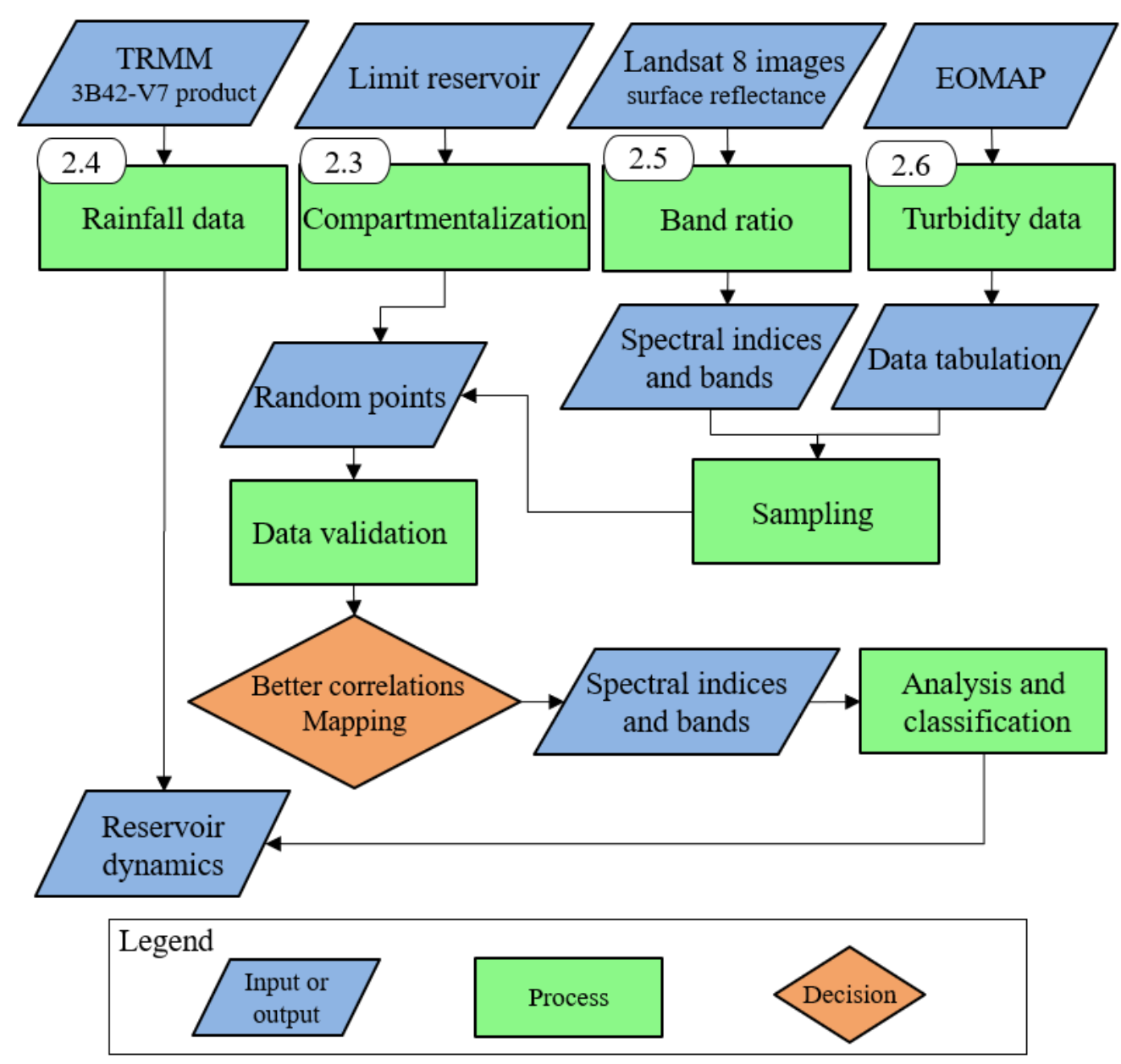

Figure 2 Methodological flowchart 
methodology, considering three aspects: (1) the characteristics of the reservoir and its hydrographic basins; (2) the hydrodynamic order of the reservoirs, regarding upstream, intermediate and downstream stations formation; (3) the formation of sequence or non-sequence of reservoirs. It was determined a 100-m zone (measured from the bank) around the reservoir to avoid spectral mixing with other targets than the water.

\subsection{TRMM Precipitation Data}

One of the main problems in the data collection on rainfall is the lack of pluviometric stations, causing the absence of data, which makes it impossible to use historical series (Moraes et al. 2015; Oliveira Junior et al. 2014). Satellite data have been used in climatological and hydrological studies, being an alternative to overcome the failing of local rainfall stations (Adams, Souza \& Costa 2009; Longo, Camargo \& Silva Dias 2004; Oliveira Junior et al. 2014).

Almeida et al. (2015); Danelichen et al. (2013); Liu (2015); Pereira et al. (2013); Pessi et al. (2019) and Serrão et al. (2016) highlight that estimates of data sets from the Tropical Rainfall Measuring Mission (TRMM) sensor (3B43 product), made available on NASA's Giovanni platform, are reliable and can be used to estimate precipitation.

The TRMM satellite, launched on November 27, 1997, from a partnership between NASA and the Japanese Aerospace Exploration Agency (JAXA), aims to both monitor precipitation in the tropics and verify its influence on global climate. The satellite's low polar orbit (initially, $350 \mathrm{~km}$, and, since 2001, $403 \mathrm{~km}$ ), together with its short translation period (91 minutes) allows the collection of high temporal and spatial resolution images (NASA 2018).

TRMM precipitation data (3B42-V7 product), obtained with a 3-hour-time resolution and $0.25^{\circ} \times 0.25^{\circ}$ spatial resolution (approximately $27 \mathrm{~km} \mathrm{x} 27 \mathrm{~km}$ ), have been used to analyze the turbidity variation. Two areas have been defined for precipitation samples (Figure 1): one from the north side of the reservoir, on the coordinates: $-54.3459,-23.7262,-53.7087,-23.1879$, and another one from the west side of the reservoir, on the coordinates: $-54.0512,-24.7856,-53.5019,-24.2912$. It was collected, also, the precipitation data for the last 5,10 and 15 days for the dates: 2016-08-11, 2016-08-27, 2016-09-28 (Table 1), which were compatible with the Landsat 8 images analyzed. These data were used both to analyze the influence of precipitation on the variation of turbidity in the reservoir and to evaluate the water flow in vertical and horizontal directions of the reservoir.

\subsection{Landsat 8 Images and Spectral Indices}

Landsat 8 satellite's Operational Land Imager (OLI) sensor provides multispectral bands from visible to shortwave infrared (SWIR), with a $185 \mathrm{~km}$ bandwidth, a 12bit radiometry and a 30-m spatial resolution. Three images were purchased on USGS Earth Explorer website (http:// earthexplorer.usgs.gov), with dates of August 11, August 27 and September 28, 2016, all with surface reflectance according to Landsat Collection 1 Level 2 product.

The selected dates have different precipitation characteristics: the 08/11 image concentrates the precipitation in the western region of the reservoir and the $08 / 27$ image concentrates the highest precipitation in both north and west regions. In the image of $09 / 28$, there is the lower rainfall in both north and west sides.

For the analysis of the turbidity in Itaipu Reservoir, we used the following water spectral indices: (a) Normalized Difference Water Index (NDWI), in which the water will have positive values while soil and terrestrial vegetation features will tend to have zero or negative values (McFeeters 1996); Modified Normalized Difference Water Index (MNDWI) in which where the NIR band was substituted by the SWIR band to improve distinction of built-up features over water (Xu 2006); and Normalized Difference Turbidity Index (NDTI) in which as turbidity level of water increases due the increase in the suspended particles in the water, the reflectance of the red band is more than that of the green band (Lacaux et al. 2007). Both which were obtained from arithmetic operations of the ENVI 5.3 software (Table 2); and (b) Landsat 8 satellite's B2 (Blue), B3 (Green), B4 (Red), B5 (NIR), B6 (SWIR 1) and B7 (SWIR 2) spectral bands. Both spectral indices and bands were related to the turbidity data, obtained from the correlation coefficient (R), to estimate the association level between two variables and the determination coefficient $\left(\mathrm{R}^{2}\right)$. Together, they are indicated to measure the fluctuation of one variable that is explained by another.

Both indices and spectral bands with higher $\mathrm{R}$ and $\mathrm{R}^{2}$ values were used in the characterization of the turbidity in the compartments of the Itaipu Reservoir. Using the maximum and minimum values of the indices, and the spectral data with the highest correlation with turbidity, the reservoir boundary was divided into identical intervals to report and analyze the compartments with the greatest influence of turbidity. 
Table 1 Precipitation data from the TRMM sensor, product 3B42-V7 from the last 5, 10 and 15 days for the dates: 2016-08-11, 201608-27, 2016-09-28.

\begin{tabular}{|c|c|c|c|c|c|c|c|c|}
\hline \multirow[b]{2}{*}{ Dates } & \multicolumn{4}{|c|}{ Precipitation North } & \multicolumn{4}{|c|}{ Precipitation West } \\
\hline & last 15 days & last 10 & last 05 & total $\mathrm{mm}$ & last 15 days & last 10 & last 05 & total $\mathrm{mm}$ \\
\hline $08 / 11$ & 0 & 0 & 12 & $12 \mathrm{~mm}$ & 0 & 0 & 64 & $64 \mathrm{~mm}$ \\
\hline $08 / 27$ & 0 & 150 & 32 & $182 \mathrm{~mm}$ & 50 & 109 & 0 & $159 \mathrm{~mm}$ \\
\hline $09 / 28$ & 0 & 21 & 0 & $21 \mathrm{~mm}$ & 0 & 45 & 0 & 45 mm \\
\hline
\end{tabular}

Table 2 Water Spectral indices

\begin{tabular}{lccc}
\hline Index & Equation & Values Range & Source \\
\hline NDWI & (Green - NIR) / (Green + NIR) & -1 a +1 & McFeeters (1996) \\
MNDWI & $($ Green - SWIR) / (Green + SWIR) & -1 a +1 & Xu (2006) \\
NDTI & (Red - Green) / (Red + Green) & -1 a +1 & Lacaux et al. (2007) \\
\hline
\end{tabular}

Legend: NDWI - Normalized Difference Water Index; MNDWI - Modified Normalized Difference Water Index; NDTI - Normalized Difference Turbidity Index.

These values were used to classify the reservoir into three turbidity levels: low, medium and high, based on both average and standard deviation statistical parameters, according to (Sharma et al. 2015; Singh, Bhardwaj \& Verma 2020; Somvanshi et al. 2011) protocols (Table 3), which were calculated by the R software. Bid \& Siddique (2019) followed this methodology of reservoir classification in turbidity analysis.

\subsection{Turbidity Validation Samples}

Turbidity (TUR) is a key parameter of water quality and it is linearly related to the inverse dispersion of light by both organic and inorganic particles. It is also linearly related to the Total Suspended Solids (TSS) (Sagan et al. 2020).

Earth Observation and Environmental Services (EOMAP) has developed, for the year 2016, algorithms based on modular inversion processing (MIP), a multisensors operating processor designed to extract quantitative information about aquatic environments from remote sensing data of Landsat 5/7/8 and Sentinel-2 satellites (Dörnhöfer et al. 2018; EOMAP 2020; Heege et al. 2014).
Among the available products, there are historical turbidity series.

These cited algorithms allow recovering atmospheric parameters in the water, including the correction of the terrestrial adjacency effect, essential for the accurate remote detection of any coastal or inland water body. They contain a physical and accurate implementation of the bidirectional effect within the water column, on the surface and in the atmosphere, considering, yet, the full range of reflective, absorbent and dispersion properties of the water body and its limits with the atmosphere (Dörnhöfer et al. 2018; EOMAP 2020; Heege et al. 2014).

To determine the index with the highest level of correlation with turbidity, samples of turbidity were obtained from its historical series for the year 2016, available at EOMAP. Were used 195 random samples in the 18 Formazine Turbidity Unit (FTU) turbidity compartments for each image date, in order to validate both indices and spectral bands from the Landsat 8 images. For the horizontal compartments (4 to 18 ), were collected 10 samples per compartment and, for the vertical compartments (1 to 3), it were collected 15 samples per compartment.

Table 3 Turbidity classification, according to Somvanshi et al. (2011) and Sharma et al. (2015).

$\begin{array}{cc}\text { Low Turbidity } & \text { Mean }- \text { Standard Deviation }(>+1 \sigma) \\ \text { Medium Turbidity } & \text { Mean }+ \text { Standard Deviation } \\ \text { High Turbidity } & \text { Value of more than Medium Turbidity }\end{array}$


The spectral data most closely related to the validation data underwent statistical evaluation to analyze the degree of similarity of the individual compartments and the reservoir by ANOVA analysis of variance: (1) For the analysis of the dynamics of the individual compartments, the null hypothesis $(\mathrm{H} 0)$ was that there are no significant differences between the mean values of the compartments; (2) For the analysis of the dynamics of the reservoir, the null hypothesis (H0) was that there are no significant differences between the mean values of all compartments. The null hypotheses were tested by calculating an $\mathrm{F}$ value at a significance level of 0.05 .

\section{Results and Discussion}

\subsection{Compartmentation}

Three compartments in the total were defined in the central body of the reservoir (upstream, intermediate and downstream), as well as 15 compartments were defined in the horizontal arms, corresponding to the tributary river basins (Figure 1). Due to the large extension of the reservoir, compartmentalizing the Itaipu Reservoir into 18 compartments, based on the methodology of Wachholz, Pereira Filho \& Sartor (2011), allowed the analysis of turbidity dynamics in more homogeneous areas.

\subsection{Bands Ratio}

This study showed that the turbidity data obtained from EOMAP showed the higher correlation between band 4 (red region, $\sim 655 \mathrm{~nm}$ ) of OLI/Landsat 8 and the NDTI index (Table 4). So we chose to discard further analysis with the other bands and indexes that showed low correlation.

In the relationship between turbidity and red band (B4), according to the dispersion graphic on Figure $3 \mathrm{~A}$, it can be seen a positive correlation (R) of 0.97 and a determination coefficient of 0.94 . Between turbidity and NDTI index, the correlation (R) was 0.95 and the determination coefficient was 0.91 (Figure 3B).

The most of methods to interpret turbidity fluctuation in lakes and reservoirs propose specific empirical relationships by adjusting the in-situ turbidity measurements with the reflectance that is derived from satellite bands (Dogliotti et al. 2015). A single band or the ratio between two bands is routinely used on turbidity analysis, as well as other water component models (Ouillon 2003).

Table 4 Correlation values and determination coefficients for the indices and turbidity versus spectral bands.

\begin{tabular}{cccc}
\hline \multirow{2}{*}{ Spectral Indices and Bands } & \multicolumn{2}{c}{ Estatísticas } & \\
\cline { 2 - 4 } & $\mathbf{R}$ & $\mathbf{R}^{\mathbf{2}}$ \\
\hline NDWI & -0.40 & 0.16 \\
MNDWI & -0.12 & 0.01 \\
NDTI & $\mathbf{0 . 9 5}$ & $\mathbf{0 . 9 1}$ \\
B2 & 0.23 & 0.05 \\
B3 & 0.68 & 0.46 & $\mathbf{0 . 9 4}$ \\
B4 & $\mathbf{0 . 9 7}$ & 0.17 \\
B5 & 0.42 & 0.02 \\
B6 & 0.15 & 0.02 \\
B7 & 0.14 & \\
\hline
\end{tabular}
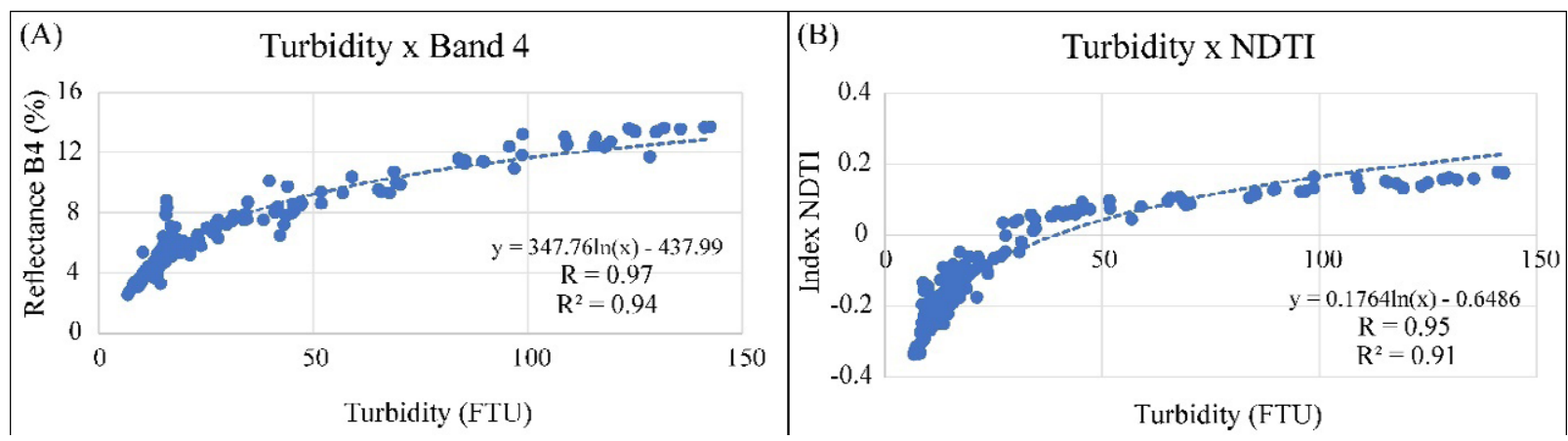

Figure 3 A. relationship between Turbidity and Red band (B4); B. relationship between Turbidity and NDTI in the Itaipu Reservoir. 
Several researchers who use remote sensing reflectance for turbidity analysis, as well as for TSS analysis, show high correlation between the red band and its concentrations (Garaba \& Zielinski 2015; Güttler, Niculescu \& Gohin 2013; Lobo, Costa \& Novo 2015; Quang et al. 2017; Vanhellemont \& Ruddick 2014). However, few studies in the literature have evaluated the relationship between water turbidity data and the NDTI index. Baughman et al. (2015) used Landsat TM image to analyze the relationships between turbidity and red band and between turbidity and NDTI index, finding 0.55 and 0.53 for $\mathrm{R}^{2}$, respectively.

Bid \& Siddique (2019) analyzed the relations between suspension sediments and NDTI, with $\mathrm{R}^{2}$ of 0.90 , and they found high turbidity from July to September in the Panchet Hill Dam. Among the several factors affecting turbidity, Göransson, Larson \& Bendz (2013); Zhang et al. (2016), report that intense rainfall events, from river discharges, are considered one of the main contributors to turbidity increment.

\subsection{Turbidity, Spectral Reflectance in the Red Wavelength and NDTI Analysis}

The values of turbidity, band 4 and NDTI for the 18 compartments are presented in Figure 4. In the 08/11 image, the compartments located in the western region of the reservoir $(11,12,13,14,15$ and 16) have turbidity values between 7 and $68 \mathrm{FTU}$, the band 4 reflectance varied between $0.02 \%$ and $0.09 \%$ and the NDTI oscillated between -0.27 and 0.10 .

We found similar behavior in the same compartments of 2016-09-28 image (Figure 4), in which the values of turbidity, reflectance in the red wavelength and NDTI varied between 6 and $59 \mathrm{FTU}$, between $0.03 \%$ and $0.08 \%$ and between -0.23 and 0.05 , respectively. The similarity between the data is directly related to the low precipitation in the northern and western regions in the reservoir.

For the image of $08 / 11$, even with the higher precipitations on the western side of the reservoir $(55 \mathrm{~mm}$ accumulated in the last 5 days), the lateral compartments did not influence in the increase of sediment transport to the reservoir.

In the image of $08 / 27$, the upstream compartments of the reservoir $(1,4,11$ and 12), in medium course (2), presented the higher values of turbidity, band 4 and NDTI. On this date, according to TRMM data, the highest precipitation occurred in the northern region of the reservoir (192 $\mathrm{mm}$ accumulated in the last 15 days), resulting in the contribution of the flood plain in the turbidity transport. According to Quang et al. (2017), the turbidity is strongly influenced by the runoff after high rainfalls, since these brings large amounts of sediment to the water body. Besides, intense water flows cause resuspension after heavy rains. The values of turbidity, band 4 and NDTI for the compartments $11,12,13,14,15$ and 16 varied between 9.1 and $128.41 \mathrm{FTU}$, between $0.03 \%$ and $0.13 \%$ and between -0.25 and 0.15 , respectively.

ANOVA analysis of variance was used for the 18 individual compartments to verify their dynamics. For the variable Turbidity, an F of 1.32 was obtained with $\mathrm{p} 0.24$, accepting the $\mathrm{H} 0$ hypothesis in which the values of the individual compartments are similar to each other and do not present a significant difference. As shown in Figure 4, compartments 1, 11, 12, 4 and 2 have greater variance, the others have very close values. For Band 4 (RED) F 1.31 with $\mathrm{p} 0.25$ also accepting the $\mathrm{H} 0$ hypothesis, the compartments with the highest variance were $1,11,12,4$ and 2 , the others with low variance. For NDTI, F was 3.68 and $\mathrm{p}<0.05$, in which we accept hypothesis $\mathrm{H} 1$ in which the compartments do not have similarity, that is, they present a significant difference, with emphasis on compartments $1,11,12,2,4,5$ and 14.

Our work and the others cited used precipitation to analyze turbidity and all report the importance of this variable in the dynamics of water bodies. Viviano et al. (2017) used precipitation data for turbidity analysis and observed higher concentrations of suspended solids and turbidity some hours after precipitations. Robert et al. (2016) highlight that periods of the year with higher precipitation have higher turbidity in reservoirs. Quang et al. (2017) showed that turbidity is influenced by precipitation in both rainy and dry seasons and that bed sediment resuspension controls turbidity in both shallow and coastal waters, while rainfall is a key factor, affecting turbidity in deep waters. In Martins et al. (2019), the level of turbidity was seasonally dependent, varying from clean water (0-20 NTU), in the dry season, to above $60 \mathrm{NTU}$, in the rainy season.

Our results are related to Buffon (2016), who analyzed the relationship between the concentration of suspended solids and band 4 of the Landsat 8 satellite in two compartments of the Itaipu Reservoir (12 and 18) (Figure 1). In low precipitation periods, the compartment 18 presented a little higher value in relation to the 12 . Robert et al. (2016) observed a significant increase in turbidity values between 2000 and 2015, and highlighted that this increase is related to changes in the land use. 


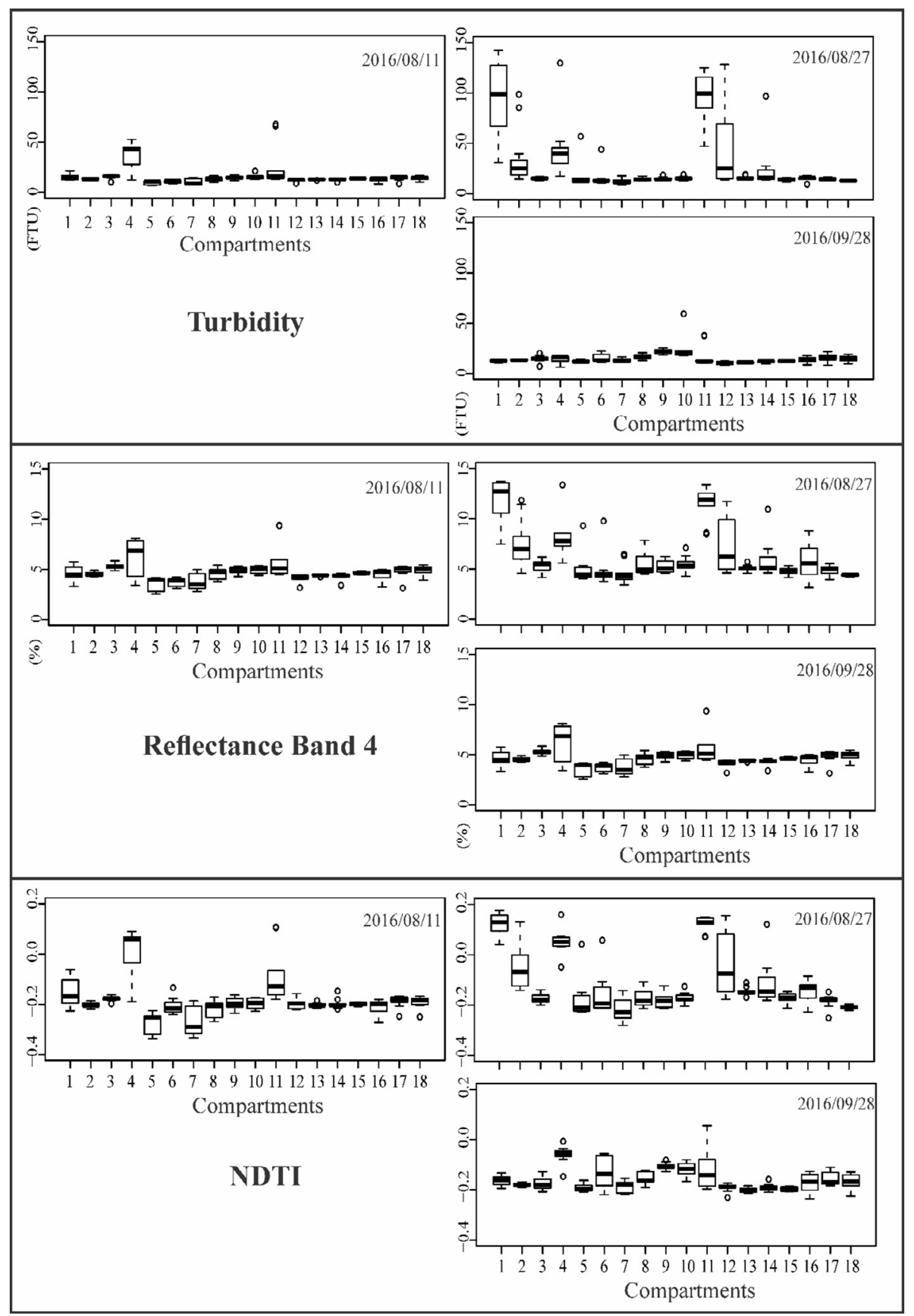

Figure 4 Boxplot of the relationship between turbidity, band 4 (OLI) and NDTI. 


\subsection{Turbidity Dynamics in the Reservoir}

NDTI values were classified into high, medium and low turbidity levels, by using average and standard deviation statistical parameters (Table 5). Both NDTI values map (Figure 5 ) and turbidity classes map, according to Sharma et al. (2015); Singh, Bhardwaj \& Verma (2020); Somvanshi et al. (2011) (Figure 6), show the spatialtemporal variation of these variables.
The 08/27 image shows the highest NDTI values (Figure 5) in the upstream area of the reservoir. Compartments 1 and 2 were classified as high turbidity (Figure 6). Current flow and turbidity variables are positively related, since the flow caused by the rains increases the sediment transportation. In addition, the current flow is strong enough to increase turbidity by causing the resuspension of the sediments deposited at the bottom of the reservoir (Fondriest Environmental Inc 2014; Yu, Zhang \& Lemckert 2014).

Table 5 Turbidity Values

\begin{tabular}{|c|c|c|c|}
\hline \multicolumn{4}{|c|}{ NDTI values of Itaipu Reservoir } \\
\hline Standard deviation & 0.093 & Average & -0.150 \\
\hline \multicolumn{2}{|c|}{ Low } & \multicolumn{2}{|c|}{-0.243} \\
\hline \multicolumn{2}{|c|}{ Medium } & \multicolumn{2}{|c|}{-0.057} \\
\hline \multicolumn{2}{|c|}{ High } & \multicolumn{2}{|c|}{$>0.057$} \\
\hline
\end{tabular}

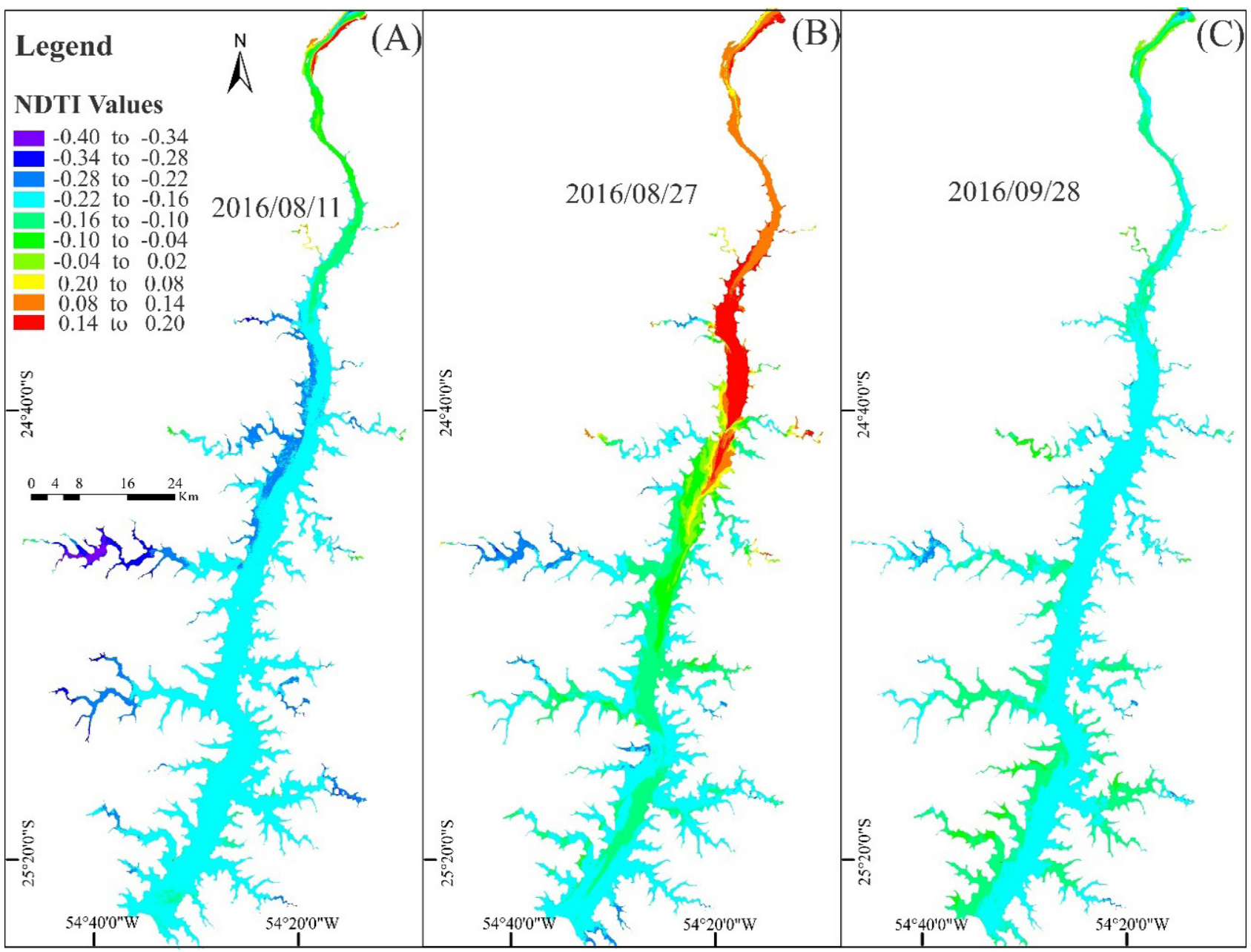

Figure 5 NDTI dynamic for the Itaipu Reservoir. 


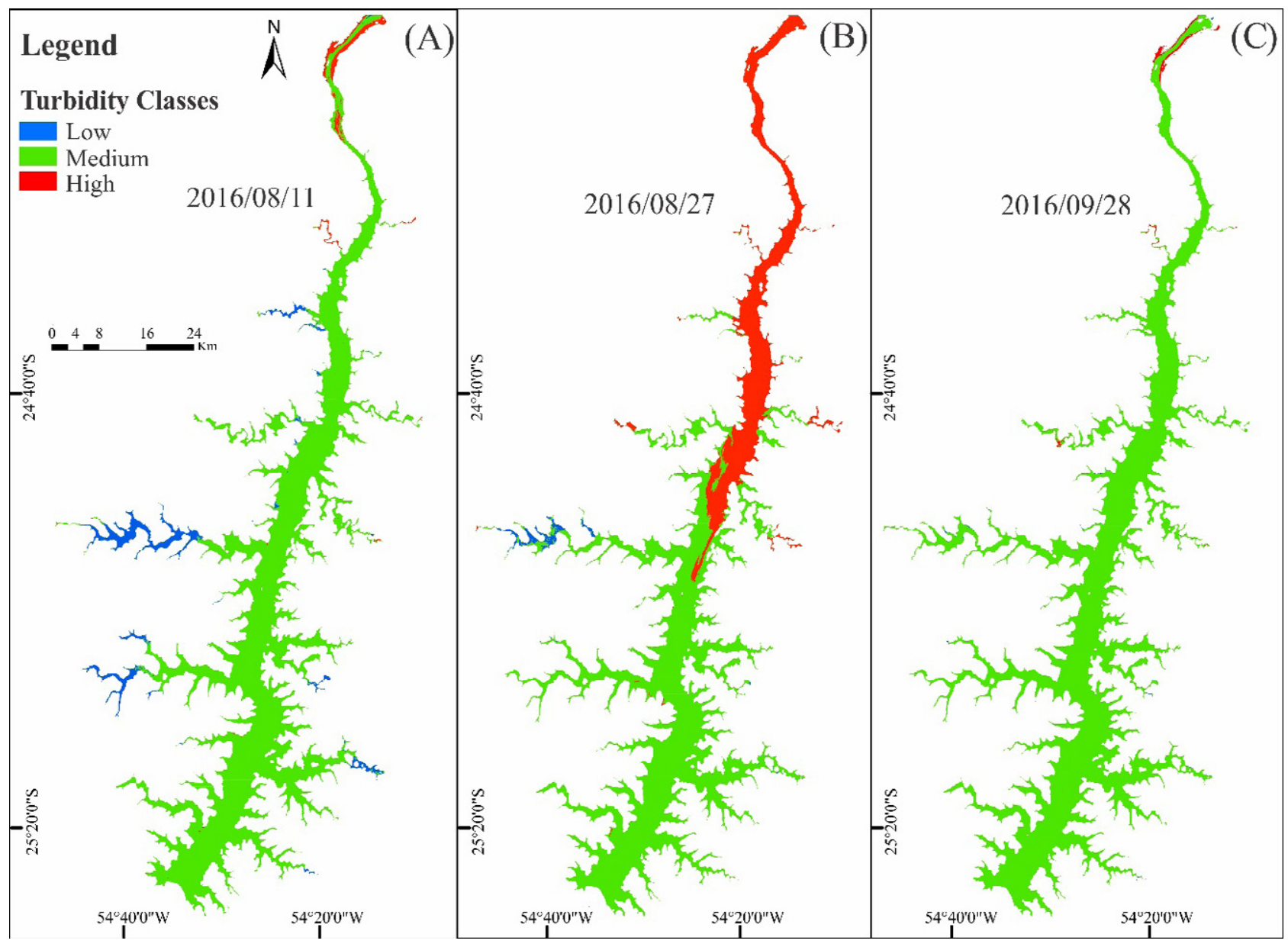

Figure 6 Turbidity classes for the Itaipu Reservoir.

The image of 09/28 showed higher NDTI values than the image of $08 / 11$ in the downstream intermediate compartments (Figure 5). The predominance of the middle turbidity class on $08 / 11$ and $09 / 28$, as well as in the reservoir as a whole (Figure 6), is due to the low rainfall in the north of the reservoir $12 \mathrm{~mm}$ and $21 \mathrm{~mm}$ respectively (Table 1) and the damming of solids by the flood plain.

Some turbidity patterns were found in the reservoir, even with different periods and precipitation, as is the case of the compartments 3 (medium turbidity), 16 (medium turbidity), 4 (high turbidity and 7 , which had low turbidity on the east of the compartment and medium turbidity on the west of the compartment, near the central body.

In the ANOVA analysis to analyze the dynamic space of the reservoir, the variable Turbidity, Band 4 (Red) and NDTI obtained F calculated from 4.93, 6.94 and 8.57 respectively with $\mathrm{P}<0.05$ for all, this means that we accept hypothesis $\mathrm{H} 1$ in which for the 3 analyzed dates independently variable the results obtained do not have similarity.

The variability of NDTI values shows that precipitation has a strong influence on the turbidity dynamic in the reservoir, being the Paraná River, in periods of higher precipitation, the main solids transportation agent in the reservoir. In addition, we found that the lateral compartments have little influence on the entrance of solids into the reservoir, as a result of the lower precipitation levels and the few amount of sediment transportation from the western side of the reservoir.

Andrade et al. (1988); Ribeiro Filho (2006) and Ribeiro Filho et al. (2011) point out that both turbidity and suspended solids showed decreasing averages towards downstream in the Itaipu Reservoir, which can be explained by precipitation events. In this sense, the fluvial zone presented the highest concentrations of suspended sediments and turbidity. 
Several works report the importance of the flood plain in retaining the solids, as well as highlight the flood periods, in which the water level of the Paraná River is higher. In these periods, characterized by flood pulses, there is the death of vegetation and the entry of solids, as a result of the increment of the water flow (Couto, Hayakawa \& Souza-Filho 2010; Hayakawa et al. 2010; Junk, Bayley \& Sparks 1989; Souza Filho \& Fragal 2013). Similar results were found by Ribeiro, Brandimarte \& Kishi (2005), who observed that after the formation of the Salto Caxias reservoir, there were significant increases in water transparency levels, with a tendency to higher values along the central axis.

In our work, values above 50 FTU were found in upstream compartments 1 and 11 on the wettest date of $08 / 27$, and values between 10 and 30 FTU for the least influenced compartments, mainly on 11/08 and 09/28 of less precipitation. Similar values were found by Martins et al. (2019) in which found that the turbidity dynamic in Sobradinho reservoir Northeast Brazil, present strong variability between rainy and dry seasons. Turbidity levels varied from clean water (0-20 NTU) during the dry season, to turbidity (> 50 NTU) during the rainy season.

Silva et al. (2009) found higher turbidity values observed in Peti reservoir, Minas Gerais Brazil, that both variations and high turbidity peaks were higher on the upstream of the reservoir (approximately $200 \mathrm{NTU}$ ) in the rainy season, oscillating between 50-80 NTU in the intermediate region. They point out that these values are influenced by anthropic activities, such as livestock, agriculture and urban solids of the cities. The Peti Reservoir and the Itaipu Reservoir are located in the Atlantic Forest Biome, which has been suffering a great deal of deforestation in recent years, according to Santos et al. (2020) the increase in the Brazilian population and the consequent expansion of areas destined for agriculture, livestock, urban centers and forestry were the main reasons for the deforestation of the biome's forests, contributing to the increase in turbidity in the reservoirs.

Agência Nacional das Águas (2021); Silva, Abdon \& Rossi (2009); Silva, Neves \& Basotti (2017) report that the silting and erosion on the banks of the Paraná River is due to the deforestation of vegetation areas on the coast of the river. The speed of the water flow of the Paraná River, in its main channel, varies between 0.8 and 1.2 m.s-1, and may present slightly higher values during the period of greater precipitation. Places protected by islands or bars, for example, have lower speeds (Galvão, Stevaux \& Saad 2014).

Studies in other reservoirs also highlight that land use and land cover is an important factor when talking about the dynamics of turbidity and suspended solids in reservoirs. Wachholz (2011) reports that in Rodolfo Costa e Silva reservoir, Rio Grande do Sul, Brazil, the type of land use is determinant in erosive processes in the watershed, as well as it influences the characteristics of the reservoir. In addition, the author states that positive correlations were found between suspended solids and exposed soil on land prepared for agricultural cultivation. Cabral et al. (2013) point out that the Caçu reservoir, Goiás, Brazil, the highest values of turbidity occurred in the upstream sector, whose main cause are the erosive processes in the margins and unprotected areas of vegetation.

Chelotti et al. (2019) generated models for estimating suspension sediment concentration from MODIS and Landsat 8 data, which allowed investigating their both temporal and spatial behavior, in relation to the rainfall regime and reservoir variation quota. According to Zhang et al. (2016), reservoirs exhibit spatial heterogeneity, significantly greater in arriving rivers than in the main body of the reservoir. According to these authors, and equally to our work the main cause is rainfall. Additionally, they have developed a semiannual model to monitor quantitatively the total of suspended material in slightly turbid inland waters, by using Landsat 8 OLI images.

Bid \& Siddique (2019), analyzing seasonal variations on the water turbidity of a dam by the application of NDTI method, showed that the highest levels of turbidity occur in the monsoon, when the indicator jumped from $60 \mathrm{NTU}$ to 700 NTU.

EOMAP's turbidity data were essential to validate both NDTI and band 4 indicators, especially when they are applied to large reservoirs that are located in the remote or difficult to access regions, on which there are lack of information on limnological parameters. The MIP system has been operationally proven in several regional monitoring applications, as well as in global water quality research, such as by UNESCO (Dörnhöfer et al. 2018; EOMAP 2020; Heege et al. 2014; Heege, Schenk \& Wilhelm 2019). In Yanti, Susilo \& Wicaksono (2016), the band 4 of Landsat 8 OLI sensor had the best precision to detect suspended sediments, presenting a determination coefficient of 0.54 .

In this work, we show that the applicability of bands and spectral indices using two bands is a simple method and provided important information about the dynamics of the reservoir. The method proposed by Sharma et al. (2015); Singh, Bhardwaj \& Verma (2020); Somvanshi et al. (2011), is efficient for identifying zones with different turbidity levels, helping in the management and monitoring of sediments in a reservoir.

The compartmentation of the Itaipu Reservoir, according to Wachholz (2011) methodology, was essential to 
the analysis of the turbidity dynamics of that homogeneous areas, considering the large extension of the reservoir. The upstream compartment 1 is characterized by giving Paraná River's largest contributions at the entrance of suspended solids into the reservoir. In downstream intermediate sector and in reservoir's side arms, the water flow becomes more lentic, because of the low stream.

For Garg, Aggarwal \& Chauhan (2020), the remote sensing approach can be used to make qualitative estimates of turbidity, even in the absence of field observations. In this sense, our analysis brought new elements to understand the turbidity fluctuation in the compartments of the Itaipu Reservoir and to comprehend the dynamics of spectral reflectance in the spatial-temporal characterization related to turbidity.

\section{Conclusions}

This work investigated the relationship between turbidity, precipitation and spectral reflectance in the Itaipu hydroelectric plant reservoir. The results reveal that higher rainfall periods have a strong influence on sediment transportation to the reservoir. The flood plain of the Upper Paraná River, which is upstream from the Itaipu Reservoir, helps in the retention of solids, but in periods of higher precipitation, the Paraná River is the main responsible for transporting sediments to the reservoir, due to its flood and water flow.

The relationship between precipitation, spectral reflectance of Landsat 8 OLI sensor's band 4, NDTI index and EOMAP's turbidity validation data showed itself strong. Both were important to illustrate that the suspended material that affects the spectral reflectance in the spatial-temporal characterization of the reservoir turbidity comes from the upstream, as well as that the horizontal compartments have little influence. The optical properties of the water indicate the red region of the electromagnetic spectrum as the one with the best potential for turbidity analysis, since it is the spectral range with the largest variation, regarding turbidity. The space-time scale approach is essential to determine and correctly interpret the differential effects generated by turbidity control processes. In this sense, this work will continue, aiming at new evaluations with more images to expand the time series. The products and methodology generated by this work are an alternative for monitoring other reservoirs.

\section{References}

Abe, C.A., Lobo, F.L., Novo, E.M.L.M, Costa, M. \& Dibike, Y. 2019, 'Modeling the effects of land cover change on sediment concentrations in a gold-mined Amazonian basin', Regional
Environmental Change, vol. 19, no. 6, pp. 1801-13. https:// doi.org/10.1007/s10113-019-01513-8

Adams, D.K., Souza, E.P.D. \& Costa, A.A. 2009, 'Moist convection in Amazonia: implications for numerical modelling', Revista Brasileira de Meteorologia, vol. 24, no. 2, pp.168-78. https:// doi.org/10.1590/S0102-77862009000200006

Agostinho, A.A., Ambrósio, A.M., Ferreira, V.S., Oliveira, E.F., Okada, E.K \& Suzuki, H.I. 1999, 'Reservatório de Itaipu: aspectos biológicos e socioeconômicos da pesca'. Relatório Anual (1997/98). UEM-Nupélia e Itaipu Binacional, Maringá.

Allam, M., Khan, M.Y. \& Meng, Q. 2020, 'Retrieval of Turbidity on a Spatio-Temporal Scale Using Landsat 8 SR: A Case Study of the Ramganga River in the Ganges Basin, India', Applied Sciences, vol. 10, no. 11, p. 3702. https://doi.org/10.3390/ app10113702

Almeida, C.T.D., Delgado, R.C., Oliveira Junior, J.F.D., Gois, G. \& Cavalcanti, A.S. 2015, 'Avaliação das estimativas de precipitação do produto 3B43-TRMM do Estado do Amazonas', Floresta e Ambiente, vol. 22, no. 3, pp. 279-86. https://doi.org/10.1590/2179-8087.112114

Alsdorf, D.E., Rodríguez, E. \& Lettenmaier, D.P. 2007, 'Measuring surface water from space', Reviews of Geophysics, vol. 45, no. 2. https://doi.org/10.1029/2006RG000197

Agência Nacional das Águas 2021, Região Hidrográfica do Paraná, viewed 15 May 2021, <http://www2.ana.gov.br/ Paginas/portais/bacias/parana.aspx $>$.

Andrade, L.F., Brunkow, R.F., Xavier, C.F., \& Domingues, L.L. 1988, 'Fitoplâncton e características físico-químicas do reservatório de Itaipu (BR)', Limnologia e manejo de represas. Série Monografias em Limnologia, vol. 1, pp. 205-68.

Barbosa, C.C.F., Novo, E.M.L.M., \& Martins, V.S. 2019, 'Introdução ao Sensoriamento Remoto de Sistemas Aquáticos: princípios e aplicações', vol. 1. Instituto Nacional de Pesquisas Espaciais.

Baughman, C.A., Jones, B.M., Bartz, K.K., Young, D.B. \& Zimmerman, C.E. 2015, 'Reconstructing turbidity in a glacially influenced lake using the Landsat TM and ETM+ surface reflectance climate data record archive, Lake Clark, Alaska', Remote Sensing, vol. 7, no. 10, pp. 13692-710. https://doi.org/10.3390/rs71013692

Bid, S. \& Siddique, G. 2019, 'Identification of seasonal variation of water turbidity using NDTI method in Panchet Hill Dam, India', Modeling Earth Systems and Environment, vol. 5, no. 4, pp. 1179-200. https://doi.org/10.1007/s40808-019-00609-8

Buffon, E.C. 2016, 'Caracterização limnológica e espectral de dois compartimentos aquáticos do reservatório Itaipu', Master Dissertation, Universidade Federal de Santa Maria. http:// repositorio.ufsm.br/handle/1/9477

Cabral, J.B.P., Wachholz, F., Becegato, V.A. \& Nascimento, E.S. 2013, 'Diagnóstico hidrossedimentológico do reservatório da UHE Caçu-Go', GeoFocus. Revista Internacional de Ciencia y Tecnología de la Información Geográfica, vol. 13, no. 1, pp. 25-37.

Chalov, S.R., Jarsjö, J., Kasimov, N.S., Romanchenko, A.O., Pietroń, J., Thorslund, J. \& Promakhova, E. V. 2015, 'Spatiotemporal variation of sediment transport in the Selenga River Basin, Mongolia and Russia', Environmental Earth 
Sciences, vol. 73, no. 2, pp. 663-80. https://doi.org/10.1007/ s12665-014-3106-z

Chelotti, G.B., Martinez, J.M., Roig, H.L. \& Olivietti, D. 2019, 'Space-Temporal analysis of suspended sediment in low concentration reservoir by remote sensing', Revista Brasileira de Recursos Hidricos, vol. 24. https://doi.org/10.1590/23180331.241920180061

Couto, E.V.D., Hayakawa, E.H. \& Souza-Filho, E.E.D. 2010, 'Diagnóstico dos efeitos causados pelas cheias excepcionais de 1982/1983 sobre a planície inundacional do Alto rio Paraná (PR-MS)', Revista de Geografia, Meio Ambiente e Ensino, vol. 1, no. 1, pp. 83-99.

Danelichen, V.H., Machado, N.G., Biudes, M.S. \& Souza, M.C. 2013, 'TRMM satellite performance in estimated rainfall over the midwest region of Brazil', Revista Brasileira de Climatologia, vol. 12, no. 1. http://dx.doi.org/10.5380/abclima. v12i1.31203

Davranche, A., Lefebvre, G. \& Poulin, B. 2010, 'Wetland monitoring using classification trees and SPOT-5 seasonal time series', Remote sensing of environment, vol. 114, no. 3, pp. 552-62. https://doi.org/10.1016/j.rse.2009.10.009

Dogliotti, A.I., Ruddick, K.G., Nechad, B., Doxaran, D. \& Knaeps, E. 2015, 'A single algorithm to retrieve turbidity from remotely-sensed data in all coastal and estuarine waters', Remote Sensing of Environment, vol. 156, pp. 15768. https://doi.org/10.1016/j.rse.2014.09.020

Dörnhöfer, K., Klinger, P., Heege, T. \& Oppelt, N. 2018, 'Multisensor satellite and in situ monitoring of phytoplankton development in a eutrophic-mesotrophic lake', Science of The Total Environment, vol. 612, pp. 1200-14. https://doi. org/10.1016/j.scitotenv.2017.08.219

Earth Observation and Environmental Services 2020, 'Earth Observation and Environmental Services', viewed, 1 August 2020, <http://www.eomap.com/services/water-quality/>.

EOMAP - see Earth Observation and Environmental Services.

Faye, C., Grippa, M., Kergoat, L. \& Robert, E. 2020, 'Investigating the Drivers of Total Suspended Sediment Regime in the Senegal River Basin Using Landsat 8 Satellite Images', Journal of Environmental Geography, vol. 13, no. 1-2, pp. 31-42. https:// doi.org/10.2478/jengeo-2020-0004

Fondriest Environmental Inc 2014, Turbidity, Total Suspended Solids and Water Clarity, Fundamentals Environmental Measurements. https://www.fondriest.com/environmentalmeasurements/parameters/water-quality/turbidity-totalsuspended-solids-water-clarity/

Galvão, V., Stevaux, J.C. \& Saad, A.R. 2014, ‘Análise Geoambiental dos Ambientes da Planície Aluvial do Alto Curso do Rio Paraná: Fragilidade e Impactos Ambientais Relativos ao Desenvolvimento do Uso Turístico', Geociências, vol. 33, no. 3, pp. 472-91.

Garaba, S.P. \& Zielinski, O. 2015, 'An assessment of water quality monitoring tools in an estuarine system', Remote Sensing Applications: Society and Environment, vol. 2, pp. 1-10. https://doi.org/10.1016/j.rsase.2015.09.001

Garg, V., Aggarwal, S.P. \& Chauhan, P. 2020, 'Changes in turbidity along Ganga River using Sentinel-2 satellite data during lockdown associated with COVID-19', Geomatics, Natural
Hazards and Risk, vol. 11, no. 1, pp. 1175-95. https://doi.or $\mathrm{g} / 10.1080 / 19475705.2020 .1782482$

Göransson, G., Larson, M. \& Bendz, D. 2013, 'Variation in turbidity with precipitation and flow in a regulated river system-river Göta Älv, SW Sweden', Hydrology and Earth System Sciences, vol. 17, no. 7, pp. 2529-42. https://doi. org/10.5194/hess-17-2529-2013

Grimm, A.M. 1988, 'Verificação de variações climáticas na área do lago de Itaipu', Anais do Congresso Brasileiro de Meteorologia, Rio de Janeiro.

Güttler, F.N., Niculescu, S. \& Gohin, F. 2013, 'Turbidity retrieval and monitoring of Danube Delta waters using multi-sensor optical remote sensing data: An integrated view from the delta plain lakes to the western-northwestern Black Sea coastal zone', Remote Sensing of Environment, vol. 132, pp. 86-101. https://doi.org/10.1016/j.rse.2013.01.009

Haibo, Y., Zongmin, W., Hongling, Z., \& Yu, G. 2011, 'Water body extraction methods study based on RS and GIS', Procedia Environmental Sciences, vol. 10, pp. 2619-24. https://doi. org/10.1016/j.proenv.2011.09.407

Hayakawa, E.H., do Couto, E.V., de Souza Filho, E.E., do Prado, B.R. \& Paula, P.F. 2010, 'Análise temporal da planície de inundação do alto rio Paraná (região de Porto Rico-PR) através de dados de sensoriamento remoto', Boletim de Geografia, vol. 28, no. 1, pp. 115-26. https://doi.org/10.4025/ bolgeogr.v28i1.8086

Heege, T., Kiselev, V., Wettle, M. \& Hung, N.N. 2014, 'Operational multi-sensor monitoring of turbidity for the entire Mekong Delta', International Journal of Remote Sensing, vol. 35, no. 8, pp. 2910-26. https://doi.org/10.1080/01431161.2014.890300

Heege, T., Schenk, K. \& Wilhelm, M.L. 2019, 'Water Quality Information for Africa from Global Satellite Based Measurements: The Concept Behind the UNESCO World Water Quality Portal' in A. Froehlich (ed), Space in African Society, Southern Space Studies, Springer, pp. 81-92. https:// doi.org/10.1007/978-3-030-06040-4_5

Instituto Agronômico do Paraná 2020, Cartas climáticas do Paraná. Londrina, viewed 20 October 2020, <http://www. iapar.br>.

Itaipu 2020, Itaipu Binacional, viewed 15 October 2020, <http:// www.itaipu.gov.br/>.

Junk, W.J., Bayley, P.B. \& Sparks, R.E. 1989, 'The flood pulse concept in river-floodplain systems', Canadian special publication of fisheries and aquatic sciences, vol. 106, no. 1, pp. 110-27.

Lacaux, J.P., Tourre, Y.M., Vignolles, C., Ndione, J.A. \& Lafaye, M. 2007, 'Classification of ponds from high-spatial resolution remote sensing: Application to Rift Valley Fever epidemics in Senegal', Remote Sensing of Environment, vol. 106, no. 1, pp. 66-74. https://doi.org/10.1016/j.rse.2006.07.012

Liu, Z. 2015, 'Comparison of precipitation estimates between Version 7 3-hourly TRMM Multi-Satellite Precipitation Analysis (TMPA) near-real-time and research products', Atmospheric Research, vol. 153, pp. 119-33. https:// doi.org/10.1016/j.atmosres.2014.07.032

Lobo, F.L., Costa, M.P. \& Novo, E.M.L.M. 2015, 'Time-series analysis of Landsat-MSS/TM/OLI images over Amazonian waters impacted by gold mining activities', Remote Sensing of 
Environment, vol. 157, pp. 170-84. https://doi.org/10.1016/j. rse.2014.04.030

Longo, M., Camargo, R. \& Silva Dias, M.A.F. 2004, 'Análise das características dinâmicas e sinóticas de um evento de friagem durante a estação chuvosa no sudoeste da Amazônia', Revista Brasileira de Meteorologia, vol. 19, no. 1, pp. 59-72.

Lu, S., Wu, B., Yan, N. \& Wang, H. 2011, 'Water body mapping method with HJ-1A/B satellite imagery', International Journal of Applied Earth Observation and Geoinformation, vol. 13, no. 3, pp. 428-434. https://doi.org/10.1016/j.jag.2010.09.006

Ma, M., Wang, X., Veroustraete, F. \& Dong, L. 2007, 'Change in area of Ebinur Lake during the 1998-2005 period', International Journal of Remote Sensing, vol. 28, no. 24, pp. 5523-5533. https://doi.org/10.1080/01431160601009698

Maliki, A.A., Chabuk, A., Sultan, M.A., Hashim, B.M., Hussain, H.M., \& Al-Ansari, N. 2020, 'Estimation of Total Dissolved Solids in Water Bodies by Spectral Indices Case Study: Shatt al-Arab River', Water, Air, \& Soil Pollution, vol. 231, no. 9, pp. 1-11. https://doi.org/10.1007/s11270-020-04844-z

Martins, V.S., Kaleita, A., Barbosa, C.C., Fassoni-Andrade, A.C., Lobo, F.L. \& Novo, E.M.L.M. 2019, 'Remote sensing of large reservoir in the drought years: Implications on surface water change and turbidity variability of Sobradinho reservoir (Northeast Brazil)', Remote Sensing Applications: Society and Environment, vol. 13, pp. 275-88. https://doi.org/10.1016/j. rsase.2018.11.006

McFeeters, S.K. 1996, 'The use of the Normalized Difference Water Index (NDWI) in the delineation of open water features', International Journal of Remote Sensing, vol. 17, no. 7, pp. 1425-32. https://doi.org/10.1080/01431169608948714

Mi, H., Fagherazzi, S., Qiao, G., Hong, Y. \& Fichot, C.G. 2019, 'Climate change leads to a doubling of turbidity in a rapidly expanding Tibetan lake', Science of The Total Environment, vol. 688, pp. 952-9. https://doi.org/10.1016/j. scitotenv.2019.06.339

Moraes, B.C., Sodré, G.R.C., Souza, E.B., Ribeiro, J.B.M., Filho, L.G.M., Ferreira, D.B.S. \& Oliveira, J.V. 2015, 'Climatology of Seasonal Rainfall in the Eastern Amazon', Revista Brasileira de Geografia Física, Recife, vol. 8, no. 5, pp. 1359-73.

NASA - see National Aeronautics and Space Administration.

National Aeronautics and Space Administration 2018, TRMM Instruments, viewed 2 October 2020, <http://trmm.gsfc.nasa. gov/overview_dir/ceres.html>.

Oliveira Junior, J.F.D., Delgado, R.C., Gois, G., Lannes, A., Dias, F.O., Souza, J.C. \& Souza, M. 2014, 'Análise da precipitação e sua relação com sistemas meteorológicos em Seropédica, Rio de Janeiro', Floresta e Ambiente, vol. 21, no. 2, pp. 140-9. http://dx.doi.org/10.4322/floram.2014.030

Ouillon, S. 2003, 'An inversion method for reflectance in stratified turbid waters', International Journal of Remote Sensing, vol. 24, no. 3, pp. 535-58. https://doi.org/10.1080/01431160304986

Ouni, H., Kawachi, A., Irie, M., M'Barek, N.B., Hariga-Tlatli, N. \& Tarhouni, J. 2019, 'Development of water turbidity index (WTI) and seasonal characteristics of total suspended matter (TSM) spatial distribution in Ichkeul Lake, a shallow brackish wetland, Northern-East Tunisia', Environmental Earth Sciences, vol. 78, no. 6, pp. 1-14. https://doi.org/10.1007/ s12665-019-8126-2
Pereira, G., Silva, M.E.S., Moraes, E.C. \& Cardozo, F.D.S. 2013, 'Avaliação dos dados de precipitação estimados pelo satélite TRMM para o Brasil', Revista Brasileira de Recursos Hídricos, vol. 18, no. 3, pp. 139-148.

Pessi, D.D., Santos, C.S.A.D., Nonato, J.J., Dourado, L.G.A., Silva, O.P., Bassini, R.T., \& José, J.V. 2019, 'Validação das estimativas de precipitação do satélite TRMM no Estado de Mato Grosso, Brasil', Revista de Ciências Agrárias, vol. 42, no. 1, pp. 81-90. https://doi.org/10.19084/RCA18217

Pinto, C.E., Menezes, P.H., Martinez, J.M., Roig, H.L. \& Villar, R.A. 2014, 'Uso de imagens MODIS no monitoramento do fluxo de sedimentos no reservatório de Três Marias', Revista Brasileira de Engenharia Agrícola e Ambiental, vol. 18, no. 5, pp. 507-516. https://doi.org/10.1590/S141543662014000500007

Potes, M., Costa, M.J., \& Salgado, R. 2012, 'Satellite remote sensing of water turbidity in Alqueva reservoir and implications on lake modelling', Hydrology and Earth System Sciences, vol. 16, no. 6, pp. 1623-33. https://doi.org/10.5194/hess-16-16232012

Quang, N.H., Sasaki, J., Higa, H. \& Huan, N.H. 2017, 'Spatiotemporal variation of turbidity based on landsat 8 oli in cam ranh bay and thuy trieu lagoon, vietnam', Water, vol. 9, no. 8, p. 570. https://doi.org/10.3390/w9080570

Ribeiro Filho, R.A. 2006, 'Relações tróficas e limnológicas no reservatório de Itaipu: uma análise do impacto da biomassa pesqueira nas comunidades planctônicas', PhD Thesis, Universidade de São Paulo.

Ribeiro Filho, R.A. 2008, Evolução histórica das relações tróficas e limnológicas no reservatório de Itaipu: efeitos top-down e bottom-up na produção pesqueira, Relatório final de Pós-Doutorado. UNESP, Rio Claro. https://bv.fapesp.br/ pt/bolsas/39226/evolucao-historica-das-relacoes-troficas-elimnologicas-no-reservatorio-de-itaipu-efeitos-top-down/

Ribeiro Filho, R.A., Petrere Junior, M., Benassi, S.F. \& Pereira, J.M.A. 2011, 'Itaipu Reservoir limnology: eutrophication degree and the horizontal distribution of its limnological variables', Brazilian Journal of Biology, vol. 71, no. 4, pp. 889-902. https://doi.org/10.1590/S1519-69842011000500010

Ribeiro, L.H.L., Brandimarte, A.L. \& Kishi, R.T. 2005, Formation of the Salto Caxias Reservoir (PR)- an approach on the eutrophication process. Acta Limnologica Brasiliensia, vol. 17 , no. 2, pp. 155-65.

Robert, E., Grippa, M., Kergoat, L., Pinet, S., Gal, L., Cochonneau, G. \& Martinez, J. M. 2016, 'Monitoring water turbidity and surface suspended sediment concentration of the Bagre Reservoir (Burkina Faso) using MODIS and field reflectance data', International Journal of Applied Earth Observation and Geoinformation, vol. 52, pp. 243-51. https://doi.org/10.1016/j. jag.2016.06.016

Rocha, A.S.D. \& Bade, M.R. 2018, Geografia da bacia hidrográfica do Paraná 3: fragilidades e potencialidades socioambientais, In House, São Paulo.

Saberioon, M., Brom, J., Nedbal, V., Souček, P. \& Císar̆, P. 2020, 'Chlorophyll-a and total suspended solids retrieval and mapping using Sentinel-2A and machine learning for inland waters', Ecological Indicators, vol. 113, p. 106236. https://doi.org/10.1016/j.ecolind.2020.106236 
Sagan, V., Peterson, K. T., Maimaitijiang, M., Sidike, P., Sloan, J., Greeling, B.A., Maalouf, S. \& Adams, C., 2020, 'Monitoring inland water quality using remote sensing: potential and limitations of spectral indices, bio-optical simulations, machine learning, and cloud computing', Earth-Science Reviews, p. 103187. https://doi.org/10.1016/j.earscirev.2020.103187

Santos, L.D., Schlindwein, S.L., Fantini, A.C., Henkes, J.A. \& Belderrain, M.C.N. 2020, 'Dinâmica do desmatamento da Mata Atlântica: causas e consequências', Revista Gestão \& Sustentabilidade Ambiental, vol. 9, no. 3, pp. 378-402. http:// dx.doi.org/10.19177/rgsa.v9e32020378-402

Secretaria de Estado do Meio Ambiente e Recursos Hídricos Bacias Hidrográficas do Paraná 2013, Série Histórica, Secretaria de Estado do Meio Ambiente e Recursos Hídricos Paraná, 2nd edn, Curitiba.

Serrão, E.A.O., Wanzeler, R.T.S., Santos, C.A., Gonçalves, L.J.M. Lima, A.M.M. \& Rocha, E.J.P. 2016, 'Statistical evaluation between the constellation of precipitation estimates with GPM satellite TRMM: an analysis of the river basin Solimões', Revista Brasileira de Climatologia, vol. 18, pp. 256-75. http://dx.doi.org/10.5380/abclima.v18i0.43059

Sharma, A., Panigrahy, S., Singh, T.S., Patel, J.G. \& Tanwar, H. 2015, 'Wetland Information system using remote sensing and GIS in Himach Pradesh, India', Asian Journal of Geoinformatics, vol. 14, no. 4.

Silva, A.P.D.S., Dias, H.C.T., Bastos, R.K.X. \& Silva, E. 2009, 'Qualidade da água do reservatório da Usina Hidrelétrica (UHE) de Peti, Minas Gerais', Revista Árvore, vol. 33, no. 6, pp. 1063-69. https://doi.org/10.1590/S0100-67622009000600009

Silva, B.L., Montanher, O.C., Novo, E.M.L.M., Barbosa, C.C.F., Maciel, D.A. \& Carlos, F.M. 2019, 'Relação entre o total de sólidos suspensos em corpos hídricos do alto rio paraná e imagens msi/Sentinel-2: estudo preliminar', XIX Simpósio Brasileiro de Sensoriamento Remoto, INPE, Santos.

Silva, J.S.V., Abdon, M.M. \& Rossi, M. 2009, 'Identificação de padrões de vegetação ciliar em imagens CBERS e respectivo estado de conservação', Geografia, Rio Claro, vol. 34, pp. 629-41. http://www.alice.cnptia.embrapa.br/alice/handle/ doc/663285

Silva, J., Neves, S.D.S. \& Basotti, I.S., 2017, 'Cobertura vegetal e uso da terra na bacia hidrográfica do rio Paraná no Estado de Mato Grosso do Sul, Brasil', Encuentro de Geografos de América Latina, vol. 16. https://www.embrapa.br/busca-depublicacoes/-/publicacao/1069074/cobertura-vegetal-e-usoda-terra-na-bacia-hidrografica-do-rio-parana-no-estado-demato-grosso-do-sul-brasil

Singh, S., Bhardwaj, A. \& Verma, V.K. 2020, 'Remote sensing and GIS based analysis of temporal land use/land cover and water quality changes in Harike wetland ecosystem, Punjab, India', Journal of environmental management, vol. 262, p. 110355. https://doi.org/10.1016/j.jenvman.2020.110355

Somvanshi, S., Kunwar, P., Singh, N.B. \& Kachhwaha, T.S. 2011, 'Water turbidity assessment in part of Gomti River using high resolution Google Earth's Quickbird satellite data', In Geospatial World Forum, pp. 18-21.

Souza Filho, E.E. \& Fragal, E.H. 2013, ‘A influência do nível fluviométrico sobre as variações de área de água e da cobertura vegetal na planície do alto rio Paraná', Revista Brasileira de
Geomorfologia, vol. 14, no. 1. http://dx.doi.org/10.20502/ rbg.v14i1.378

Stevaux, J.C., Martins, D.P. \& Meurer, M. 2009, 'Changes in a large regulated tropical river: The Paraná River downstream from the Porto Primavera Dam, Brazil', Geomorphology, vol. 113, no. 3-4, pp. 230-38. https://doi.org/10.1016/j. geomorph.2009.03.015

Toniolo, G.R., Gross, J.G., Gaida, W., Facco, D.S., Santos, F.C., Pereira Filho, W. 2019, 'Estimativa da transparência da água em uma área piloto do reservatório Itaipu por meio de dados do sensor Oli/Landsat-8', In: XIX Simpósio Brasileiro de Sensoriamento Remoto, INPE, Santos -SP.

Trinh, N.X., Quang, T.T., Ha, P.D., Le Xuan, T., Dinh, C.D., Thanh, T.N., Quang, T.T., Duc, T.D. \& Thanh, H.N. 2018, 'Delimitating inland aqua-ecological zones under different climate conditions in the Mekong Delta region, Vietnam', Journal of Water and Climate Change, vol. 9, no. 3, pp. 463-79. https://doi.org/10.2166/wcc.2018.181

Vanhellemont, Q. \& Ruddick, K. 2014, 'Turbid wakes associated with offshore wind turbines observed with Landsat 8', Remote Sensing of Environment, vol. 145, pp. 105-15. https://doi. org/10.1016/j.rse.2014.01.009

Viviano, G., Valsecchi, S., Polesello, S., Capodaglio, A., Tartari, G. \& Salerno, F. 2017, 'Combined use of caffeine and turbidity to evaluate the impact of CSOs on river water quality', Water, Air, \& Soil Pollution, vol. 228, no. 9, pp. 1-11. https://doi. org/10.1007/s11270-017-3505-3

Wachholz, F. 2011, 'Influência Da Bacia Hidrográfica E Características Espaço-Temporais de Variáveis Limnológicas Sobre Reservatórios No Rio Jacui - RS', PhD Thesis, Universidade Estadual Paulista. http://hdl.handle. net/11449/104345

Wachholz, F., Pereira Filho, W. \& Sartor, S.C.B. 2011, 'Influência do uso da terra e precipitação pluviométrica na formação de compartimentos aquáticos no reservatório Rodolfo Costa e Silva-RS, Brasil', Geografia, vol. 36, no. 3, pp. 551-70.

Wang, G.S., Xia, J., Zhu, Y.Z., Niu, C.W. \& Tan, G. 2004, 'Distributed hydrological modeling based on nonlinear system approach', Advances in Water Science, vol. 15, no. 4, pp. 521-525.

Wang, H.W., Kondolf, M., Tullos, D. \& Kuo, W.C. 2018, 'Sediment management in Taiwan's reservoirs and barriers to implementation', Water, vol. 10, no. 8, pp. 1034. https:// doi.org/10.3390/w10081034

Wang, X., Gong, Z. \& Pu, R. 2018, 'Estimation of chlorophyll a content in inland turbidity waters using WorldView-2 imagery: a case study of the Guanting Reservoir, Beijing, China', Environmental monitoring and assessment, vol. 190, no. 10, pp. 1-16. https://doi.org/10.1007/s10661-018-6978-7

$\mathrm{Xu}, \mathrm{H} .2006$, 'Modification of normalised difference water index (NDWI) to enhance open water features in remotely sensed imagery', International journal of remote sensing, vol. 27, no 14, pp. 3025-3033. https://doi.org/10.1080/01431160600589179

Yanti, A., Susilo, B. \& Wicaksono, P. 2016, 'The aplication of Landsat 8 OLI for total suspended solid (TSS) mapping in Gajahmungkur reservoir Wonogiri regency 2016', IOP Conference Series: Earth and Environmental Science, vol. 47, no. 1, p. 012028). 
Yu, Y., Zhang, H. \& Lemckert, C. 2014, 'Salinity and turbidity distributions in the Brisbane River estuary, Australia', Journal of hydrology, vol. 519, pp. 3338-52. https://doi.org/10.1016/j. jhydrol.2014.10.015

Zhang, Q. \& Liu, H. 2014, 'Seasonal changes in physical processes controlling evaporation over inland water', Journal of Geophysical Research: Atmospheres, vol. 119, no. 16, pp. 9779-92. https://doi.org/10.1002/2014JD021797
Zhang, Y., Zhang, Y., Shi, K., Zha, Y., Zhou, Y. \& Liu, M. 2016, 'A Landsat 8 OLI-based, semianalytical model for estimating the total suspended matter concentration in the slightly turbid Xin'anjiang Reservoir (China)', IEEE journal of selected topics in applied earth observations and remote sensing, vol. 9, no. 1, pp. 398-413. https://doi.org/10.1109/ JSTARS.2015.2509469

\section{How to cite:}

Facco, D.S., Guasselli, L.A., Ruiz, L.F., Simioni, J.P.D. \& Dick, D.G. 2021, 'Spectral Reflectance in the Spatial-temporal Dynamic of Turbidity, Itaipu Reservoir, Brazil', Anuário do Instituto de Geociências, vol. 44: 41228. https://doi.org/10.11137/1982-3908_2021_44_41228 